\title{
The Financing Options for New Small and Medium Enterprises in South Africa
}

\section{Olawale Fatoki}

Department of Business Management, Turfloop campus, University of Limpopo, Limpopo Province, South Africa

Email: Olawale.fatoki@ul.ac.za

Doi:10.5901/mjss.2014.v5n20p748

\begin{abstract}
New SMEs are critical to the reduction of the high rates of poverty and unemployment in South Africa. The failure rate of new small and medium enterprises (SMEs) is very high. Access to finance is one of the major constraints to the survival of new SMEs in South Africa. The purpose of the study was to examine the traditional and innovative financing options available to new SMEs in South Africa. The study analysed the traditional sources of equity and debt such as business angels, venture capitalists, commercial banks, trade credit and government agencies. The study suggested that one of the innovative ways to improve access to finance by new SMEs is crowdfunding. There is the need to provide a regulatory environment that will support the growth of crowdfunding in South Africa.
\end{abstract}

Keywords: new SMEs, traditional, innovative, financing options, South Africa

\section{Introduction}

Small and medium enterprises (SMEs) are increasingly seen as playing an important role in the economies of many countries. Thus, governments throughout the world focus on the development of the SME sector to promote economic growth. In South Africa, SMEs are expected to be an important vehicle to address the challenges of job creation, sustainable economic growth, equitable distribution of income and the overall stimulation of economic development (FinScope, 2010). According to the Organisation for Economic Cooperation and Development (2014), SMEs are crucial for forging new paths to more sustainable and inclusive growth because of their role in developing and diffusing innovation and providing employment.

Wong et al. (2005) point out that the contribution of the SME sector cannot be sustained without the creation of new SMEs. According to Herrington et al. (2009), new SMEs are seen as a significant component of the solution to South Africa's development issues. New business creation is fundamental to the growth of the South African economy and its future socio-political stability. The creation and sustainability of new SMEs are vital to the economic prosperity of South Africa. Without the creation of new SMEs, South Africa risks economic stagnation. A new SME can be described as a SME that has being in existence for less than forty two months. In addition, the National Small Business Act of South Africa of 1996, as amended in 2003, describes an SME as "a separate and distinct entity including cooperative enterprises and non-governmental organisations managed by one owner or more, including its branches or subsidiaries if any is predominantly carried out in any sector or sub-sector of the economy mentioned in the schedule of size standards, and can be classified as an SME by satisfying the criteria mentioned in the schedule of size standards". The criteria include turnover, number of employees and the gross asset total (Government Gazette of the Republic of South Africa, 2003).

However, despite the noted contribution of new SMEs, the creation rate of new SMEs in South Africa is one of the lowest in the world. According to Turton and Herrington (2013), South Africa's Total Entrepreneurial Activity (TEA) rate decreased from $9.1 \%$ in 2011 to $7.3 \%$ in 2012. South Africa's TEA is significantly below the average of efficiency-driven countries (14.3\%). This indicates the South Africa's consistently below-average trend in early-stage entrepreneurial activity relative to countries with a similar economic development level. South Africa's low new SME creation rate paints a bleak picture of the SME sector's current potential to contribute meaningfully to job creation, economic growth and more equal income distribution. In addition, $75 \%$ of new SMEs created in South Africa fail within the first two years of operation (Scheers, 2010). Various challenges and impediments prevent the creation of new SMEs as well as cause the high failure rates of new SMEs in South Africa. One of these is the non-availability of external financing. According to Herrington et al. (2009), access to finance is a major problem for the South African entrepreneur. Cosh et al. (2009) and the Organisation for Economic Cooperation and Development (2014) remark that an inherent problem that new entrepreneurs face is their 
inability to attract external capital, given the lack of collateral and the presence of information asymmetry with investors. This study builds on the literature on entrepreneurial finance in South Africa by examining the both the conventional and the innovative financing options that are available to new SMEs in South Africa

\section{The Objective of the Study}

New SMEs are critical to the economic development of South Africa. The failure rate of new SMEs is very high in South Africa. Access to finance is one of the major constraints to the survival of new SMEs in South Africa. The objective of the study is to examine the conventional and the innovative financing options that are available to new SMEs in South Africa.

\section{Literature Review}

\subsection{The financing needs of new SMEs}

Timmons and Spinelli (2007) point out that developing financing and fund-raising strategies, knowing what alternatives are available, and obtaining funding are tasks vital to the survival and success of most new SMEs. Winton and Yerramilli (2008) remark that once the core of the market opportunity and the strategy for seizing it are well defined, an entrepreneurial organization can then begin to examine the financial requirements in terms of (1) asset needs (facilities, equipment, research and development, and other one-time expenditures) and (2) operating needs (i.e. working capital for operations). Successful entrepreneurs anticipate the investment requirements of their firms so they can evaluate, select, negotiate, and craft business relationships with potential funding sources appropriately. Zhou and Chen (2008) submit that new SMEs need physical resources to take advantage of business opportunities. Lack of physical resources is a critical failure factor for new SMEs because opportunity discovery needs physical resources to bring it to fruition. New SME needs resources such as fixed assets and working capital to be able to achieve a competitive advantage in the market. Todor and Alin (2008), Cardon et al. (2009) and Barringer and Ireland (2012) reveal that the other reasons why new SMEs need finance include initial losses because of the cost of product development and other sunk costs before they start operation, new product development, human capital development, training and technology. This is consistent with the view of Timmons and Spinelli (2007) that the decision on what resources are needed, when they are needed and how to acquire them are strategic decisions that fit with other driving forces of entrepreneurship. Robb and Robinson (2009) point out that to undertake capital investments, meet working capital and develop products, new SMEs need finance. This can come in the form of equity, debt or a hybrid of debt and equity. These financial sources form the capital structure of a firm.

\subsection{Capital structure}

Capital structure is described as the mix of debt and equity that a firm uses to finance its operations. The capital structure decision is one of the most complex decisions facing a firm. Poor capital structure decisions can result in the high cost of capital and lower profitability. The theoretical principles underlying capital structure can generally be described in terms of the static trade-off theory by Modigliani and Miller $(1958,1963)$, the agency theory by Jensen and Meckling $(1976)$ and the pecking order theory by Myers (1984). Modigliani and Miller (1958) argue that the choice of capital structure does not affect a firm's market value. It is the assets of a firm that determine the value of the firm and not the way by which these assets are financed. The initial perfect market assumptions, on which the 1958 theory of Modigliani and Miller was based, were later reviewed in 1963 with the introduction of the tax benefits of debt. Because the interest on debt is taxdeductible, thereby creating tax savings for the borrower, it becomes possible for firms to minimize their costs of capital and maximize shareholders' wealth by using debt (Modigliani and Miller, 1963).

Jensen and Meckling (1976) identify two types of agency conflicts. The first focuses on the conflict between shareholders and managers and the second on the conflict between equityholders and debtholders. Conflicts between shareholders and managers arise because managers do not hold total residual claim thus they cannot capture the entire gain from their value-maximizing activities. The second type of conflict arises between debtholders and equityholders because debt contracts give equityholders an incentive to invest sub-optimally. According to Padachi et al. (2008) the agency theory gives vital insights into the problems of ownership, management interrelationships and credit rationing. Issues around information asymmetry, moral hazard and adverse selection are likely to arise in contractual arrangements between firms and external providers of finance. Stiglitz and Weiss (1981) point out that agency problems such as asymmetric information and moral hazards can impact on the availability of credit and hence the capital structure of new 
SMEs. Myers (1984) in the Pecking Order theory argues that there is no well-defined optimal capital structure for a firm. Management has a preference to choose internal financing before external financing. When a firm is forced to use external financing sources, managers select the least risky and demanding source first. When it is necessary to issue external sources, debt issuance is preferred to new equity.

\subsection{Traditional financing options for new SMEs}

Schwienbacher and Larralde (2010) point out that the traditional financing options available to new SMEs can be grouped under equity and debt. Table 1 illustrates the traditional financing option available to new SMEs as adapted from Schwienbacher and Larralde, (2010).

Table 1: The traditional financing options available to new SMEs

\begin{tabular}{|l|}
\hline \multicolumn{1}{|c|}{ Financing options } \\
\hline Equity \\
\hline Entrepreneur and team members \\
\hline Friends and family \\
\hline Business angels \\
\hline Venture capitalists \\
\hline Other companies/ strategic investors \\
\hline Stock markets \\
\hline Debt \\
\hline Banks/micro credit firms \\
\hline Leasing companies \\
\hline Government agencies \\
\hline Trade credit \\
\hline Bootstrapping \\
\hline
\end{tabular}

\subsubsection{Equity}

Bhaird and Lucy (2008) point out that the firm life-cycle theory suggests that SMEs should start operations with internal equity before moving to other sources of finance. New SMEs tend to draw initial capital from internal sources. As the firm ages, outside investors can observe the firm's track-record and examine its creditworthiness over time. In developing a reputation, firms attenuate the problem of asymmetric information and have improved access to short-term sources of funding such as trade credit and bank overdraft facilities. Internal equity enhances the creditability of a new SME when sourcing for external finance. Equity can be described as any financing vehicle that has a residual claim on the firm, and does not create a tax advantage from its payments; has an infinite life; does not have priority in bankruptcy, and provides management control to the owner. Equity implies the owners' financial contribution to the firm on which dividends are paid. Equity holders are the real owners of a firm. Equity holders are also called residual owners, because they receive what is left after all the claims on the firm's assets and incomes, such as debenture interests and preference share dividends, have been satisfied. They are, therefore, compensated with capital gains and dividends. Equity can be broadly divided into internal equity and external equity (Damodaran, 2001).

$\mathrm{Ou}$ and Haynes (2006) note that internal equity which can be described primarily as owners' contributions, contributions from family and friends and retained earnings, is used more widely by SMEs. The owners of a new SME contribute what is known as "sweat equity" to the firm. It is important for the firm owner to have some personal assets in the business, and this typically comes from personal savings. Also a banker or any credit provider may not grant credit to a new SME if the owner does not have his or her own money at risk. In addition, contribution from friends and family is another important source of finance for new SMEs. This form of contribution is often called "love money" which can consist of outright gifts, loans or investments. This kind of contribution often comes in the form of delayed compensation or reduced or free rent. Internal equity capital provides long-term funding with minimal cash flow drains typically associated with debt financing.

Ebiringa (2011) notes that the use of internal equity by SMEs has certain advantages. Internal equity provides managers with flexibility. In addition, SMEs avoid costs such as legal, accounting, and underwriting fees when using internal funds. Internal equity can also help SME owners maintain control of their businesses. Irwin et al. (2006) suggest that a new SME often needs to source external funds to finance growth as internal equity is often limited and inadequate. 
Therefore, there is the need for new SMEs to source external equity or debt finance.

Beger and Udell (2006) point out that external equity includes equity contribution from external sources such as business angels, venture capitalists and the stock exchange. Venture capitalists are firms who make equity investments in firms with an opportunity for growth. Venture capitalists are formal business entities that maintain strong oversight over the firms they invest in, and that have clearly defined exit strategies. Mason and Harrison (2013) ascertain that business angels on the other hand, are a diverse group of high net worth individuals who invest part of their assets in highrisk/high-return entrepreneurial ventures. They are usually wealthy investors who are willing to invest in promising early stage firms in exchange for a portion of the firm's equity. As equity partners, business angels can bring specific skills into a business. New SMEs can also source for equity investments through the stock exchange. In South Africa, the Alt X was launched in October 2003 as a parallel market to the Main board of the Johannesburg Stock Exchange (JSE). The Alt $X$ is specifically aimed at attracting SMEs to list on the JSE (Johannesburg Stock Exchange, 2014).

Despite the many sources of external equity for new SMEs, access to external equity remains a major constraint for new SMEs. This phenomenon is termed the equity gap. According to Harding and Cowlings (2006) and Baldock and North (2012), the equity gap is described as the situation where there is a shortage of equity investments during the initial stages of a firm's life-cycle. External equity finance in the form of venture capital and business angels is generally unavailable to SMEs without strong growth prospects. Access to external equity through public listing on the stock exchange is unavailable until the firm is relatively large and is able to meet the minimum size requirements for listing. Blumberg and Letterie (2008) agree that the lack of external equity makes many new SMEs dependent on debt financing.

\subsubsection{Debt}

Damodaran (2001) describes debt is as any financing vehicle that is a contractual claim on the firm, creates a tax deductible interest payment, has a fixed life and has priority claims on cash flows in both the operating and bankruptcy periods. Bankruptcy occurs when the total liabilities of a firm exceed its total assets. The principal sources of private sector debt for new SMEs are commercial banks and trade creditors. According to Feakins (2005), commercial banks are a principal source of debt finance for new SMEs. Commercial banks offer new SMEs a wide range of services in their own right or through wholly or partially owned subsidiaries. These services cover every aspect of the financial market such as overdraft facilities, term loans, trade bill financing, factoring, leasing, export and import finance, and even government loan guarantee schemes. Commercial banks are in a better position to gather information on SMEs through established relationships, which they and their staff have with SMEs and their owners. In addition, commercial banks have extensive branch networks that can be accessed by new SMEs even in remote locations. Furthermore, the financial conditions of small firms are usually rather opaque to investors, and the costs of issuing securities directly to the public are prohibitive for most SMEs. Thus, without financial intermediaries like banks it would simply be too costly for most investors to learn the information needed to provide the credit, and too costly for the small firm to issue the credit itself.

Huyghebaert et al. (2007) point out that trade credit arises when a firm purchases goods and services for which payment is delayed. SMEs can make use of trade credit as a form of credit or as a convenient alternative to paying cash each time a purchase is made. It is a spontaneous source of financing, as it arises from ordinary business transactions. However, it is evident that a supplier who offers extended credit is likely to build the cost of such credit into the pricing structure of the goods or services. Trade credit is usually extended for an intermediate period of thirty to sixty days at which point payment is due. If payment is not made on the date, financing charges are applied and trade credit becomes an alternative method of financing business expenses. Frequently, suppliers will offer cash discounts typically one percent to two percent of the purchase price for early payment not more than fifteen days after delivery. New SMEs face high failure rates in the early years of their life. This high failure rate limits their access to bank loans and they therefore tend to rely on their suppliers for financing. Love (2010) notes that trade credit is considered to be an expensive financing source if payments are not made within the stipulated credit window. Furthermore, the cost of the credit is usually imputed into the cost of goods sold on credit. This may indirectly make trade credit an expensive source of finance.

Berger and Udell (2006) remark that despite some of the disadvantages associated with trade credit, it is an extremely important source of finance for new SMEs. Trade credit may also provide a cushion during credit crunches, monetary policy contractions or other shocks that leave financial institutions less willing or less able to provide small business finance. Since only a limited number of new SMEs have access to loans from financial institutions, trade credit may often be the best or only available source of external funding for working capital.

Mazanai and Fatoki (2011) point out however that market imperfections are a strong justification for the need to provide government support to the SME sector, which, despite its significant contribution to socio-economic growth finds it difficult to survive to access external debt and equity finance from commercial banks and venture capitalists. There are 
many government agencies at national and provincial levels that provide finance to new SMEs. One of these agencies is the Small Enterprise Finance Agency (SEFA). The agency provides loan facilities directly to SMEs operating in all sectors of the economy. The facilities range from a minimum of R50 000 to a maximum of R5 million. In addition, the agency administers the credit guarantee scheme. The purpose of the scheme is to issue a range of credit guarantee products to lenders (commercial banks and other financial institutions) for SME borrowers whose access to finance is impeded by the fact that they do not have collateral required by the lenders (Small Enterprise Finance Agency, 2014). In addition, the informal finance sector consists of informal finance such as micro finance and credit and saving organisations (Gbandi and Amissah, 2014). North et al. (2010) point out that despite the existence of many sources of debt, access to debt finance is limited for SMEs especially new ones in South Africa. This is termed the debt gap. The debt gap represents the problematic flow of debt from financial agents to SMEs. FinScope(2010) points out that the incidence of loans and borrowing from the formal financial sector by new SMEs in South Africa is extremely low. Thus new SMEs have to find creative ways to obtain resources.

\subsubsection{Bootstrapping}

Winborg (2008) points out that financial bootstrapping is used by firms when internal or external finance is not available. Firms without access to formal debt or equity markets can creatively access resources through different means. Bootstrapping involves finding creative ways to avoid the need for external finance through creativity, ingenuity, thriftiness and cost-cutting. Ebben and Johnson (2006) define financial bootstrapping as the use of resourceful and innovative methods that (i) minimize the amount of finance firms need to raise through financial market transactions with traditional outside financiers and (ii) allow firms to secure resources owned by others at little or no cost. According to Vanacker et al. (2011), financial bootstrapping is a resource dependence management strategy. SME owners take actions to reduce financial uncertainty and dependence of their business by actively deploying bootstrapping techniques.

\subsection{Innovative access to finance}

\subsubsection{Crowdfunding}

The Association of Chartered Certified Accountants (2014) points out that one of the ways to increase access to finance for SMEs is for more organisations within or outside the banking system to start lending to them. Collins (2014) observes that crowdfunding provides financing for commercial ventures through multiple small-scale investors. Crowdfunding is playing an increasingly large role as a source of finance. Crowdfunding is often leveraged by small and medium enterprises and entrepreneurs, particularly those who might not otherwise be able to access finance. Crowdfunding as a source of financing can circumvent many of the limitations of traditional funding models. Schwienbacher and Larralde, (2010) observe that recently some entrepreneurs have started to rely on the Internet to directly seek financial help from the general public (the "crowd") instead of approaching financial investors such as business angels, banks or venture capital funds. This technique, called crowdfunding has made possible to seek capital for project-specific investments as well as for starting up new ventures.

Schwienbacher and Larralde (2010) note that concept of cowdfunding can be understood as an integral part of the concept of crowdsourcing. Kleemann et al. (2008) point out that crowdsourcing takes place "when a profit oriented firm outsources specific tasks essential for the making or sale of its product to the general public (the crowd) in the form of an open call over the internet, with the intention of animating individuals to make a contribution to the firm's production process for free or for significantly less than that contribution is worth to the firm" Crowdsourcing has been made possible on a large scale by the emergence of the Internet. According to Lambert and Schwienbacher (2010) the objective of crowdfunding is to collect money for investments through the use of social networks on the Internet The crowdfunders (those who provide the money) can at times also participate in strategic decisions or even have voting right. In other words, instead of raising the money from a very small group of sophisticated investors, the idea of crowdfunding is to obtain it from a large audience where each individual will provide a very small amount. Thus raising funds by tapping a general public (or the crowd) is the most important element of crowdfunding. Belleflamme et al.(2013) define crowdfunding as "an open call, essentially through the Internet, for the provision of financial resources either in form of donation or in exchange for some form of reward and/or voting rights in order to support initiatives for specific purposes". Thus, crowdfunding raises the possibility of raising capital beyond conventional sources as depicted by table 1 .

Collins (2014) asserts that four technological advances have assisted the growth of crowdfunding. These are (1) the ability to easily set up a free online platform. (2) secure online money transferring services. (3) accurate credit scores 
that can be used by many different financiers, and (4) free social media marketing tools that can be used to engage geographically dispersed large crowds of people such as Twitter, Facebook, and microblogging sites. Guidici et al. (2012) note that an increasing number of firms are entering the crowdfunding space by running crowdfunding platforms (CFPs) on the internet and funds obtained from crowdfunding is gradually increasing. CFPs may be categorized according to (i) the participation rights of crowdfunders in the project's outcome. (ii) the fees requested by CFPs to project initiators, and (iii) the services offered by the CFPs. The participation rights include (1) equity-based: this implies that crowdfunders have the right to share the residual income generated by the project. (2) lending-based: in this situation, funds are paid back and the crowdfunders have the right to receive an interest payment contractually agreed. (3) donation-based: this implies that funds are provided with no other compensation, for philanthropic or sponsorship proposal, and (4) rewardbased: in this situation, funds are provided in exchange for non-monetary benefits (e.g. a release of the product).

Collins (2014) ascertains that out that crowdfunding is expanding finance for entrepreneurs for the following reasons. (1) it provides funding when traditional providers of finance are absent. (2) it eliminates geographical barriers to raising financing. (3) it is a way to identify good investment projects. It is a unique way to validate original ideas in front of a specifically targeted audience, and (4) it attracts investment by appealing to both financial and non-financial motives of investors. However, because of the newness, crowdfunding exists in an uncertain legal and regulatory environment. Regulators are looking for ways to address potential risk to investors and promote transparency.

\section{Conclusions}

The creation and sustainability of new SMEs are vital to the economic prosperity of South Africa. The creation rate of new SMEs in South Africa is one of the lowest in the world. In addition, new SMEs suffer from a high failure rate. Various challenges prevent the creation of new SMEs as well as cause the high failure rates of new SMEs in South Africa. One of these is the non-availability of external financing. This study examined the traditional and innovative financing options available to new SMEs in South Africa. The study analysed the traditional sources of equity and debt such as business angels, venture capitalists, commercial banks, trade credit and government agencies. Despite the existence of many conventional sources of equity and debt, access to external finance is limited for new SMEs in South Africa. This is termed the finance gap. The study suggested that one of the innovative ways to improve access to finance by new SMEs is crowdfunding. However, there is the need for government to provide the regulatory environment that will support crowdfunding in South Africa.

\section{References}

Association of Chartered Certified Accountants (2014). Innovations in access to finance for SMEs. [Online] Available: http://www.accaglobal.com/content/dam/acca/global/PDF-technical/small-business/pol-afb-iiatf.pdf (May 18, 2014)

Baldock, Robert, North, David (2012), The Role of UK Government Equity Funds in Addressing the Finance Gap facing SMEs with Growth Potential. [Online] Available: www.isbe.org.uk/content/assets/10.RobertBaldockBP (May 22, 2014)

Barringer, B.R., Ireland, D. (2012). Entrepreneurship: successful launching new venture. (4th ed.) .New York: Prentice Hall.

Belleammey, P., Lambertz, T., Schwienbacherx, A., (2013). Crowdfunding: Tapping the Right Crowd, Journal of Business Venturing, 29(5): 585-609

Berger, A., Udell, G. (2006). A more conceptual framework for SME financing. Journal of Banking and Finance, 30(11): $2945-2966$.

Bhaird, Ciaran, Lucy, Brian, (2006), The financial growth life cycle: an empirical examination of Irish SMEs. [Online] Available: http://papers.ssrn.com/so13/papers.cfm?abstract-id-991296 (May 18, 2014)

Bhaird, C.M., Lucy, B. (2008). Determinants of capital structure in Irish SMEs. Small Business Economics, 4(2): 310-326

Blumberg, B.F., Letterie, W.A. (2008). Business starters and credit rationing in small business. Small Business Economics, 3(1): 187-200

Cardon, M., Wennberg, K., Wiklund, J., De Tienne, D.R. (2009). Human Capital Predictors of Entrepreneurs Exit Pattern. Journal of Business Venturing, 4(3):18-31.

Collins, Liam, (2014), Crowdfunding: Innovative access to finance and regulatory challenges [Online] Available: https://innovationpolicy platform.org/sites/default/files/rdf_imported_documents/Policy_Brief-Crowdfunding.pdf (May 26, 2014)

Cosh, A., Cumming, D., Hughes, A. (2009). Outside Entrepreneurial Capital. Economic Journal, 119(540): 1494-1533.

Damodaran, A. (2001). Corporate Finance: Theory and Practice. (2nd ed.). New York: Wiley

Ebben, J., Johnson, A. (2006). Bootstrapping in small firms: An empirical analysis of change over time. Journal of Business Venturing, 21(1): 851-865

Ebiringa, O.T. (2011). Synthesis of literature on small \& medium entreprise (SME) start-up financing. International Journal of Economic Research, 2(1), 85-95

Feakins, M. (2005). Commercial banks lending to SMEs in Poland. Small Business Economics, 1(8): 51-70. 
FinScope (2010), South Africa small business survey [Online] Available: http://www.btrust.org.za/downloads/0_nsbs_finscope_small_ business_survey_final_report_march_2011.pdf (June 5, 2014)

Gbandi, E.C., Amissah, G. (2014). Financing options for small and medium enterprises (SMEs) in Nigeria. European Scientific Journal, 10(1): $327-340$

Government Gazette of the Republic of South Africa. (2003). National Small Business Amendment Act. [Online] Available: http://www.info.gov.za/gazette/acts/2003/a26-03.pdf (June 20, 2013)

Giudici, Giancarlo, Nava Riccardo, Lamastra, Cristina, Verecondo, Chiara (2012), Crowdfunding: The New Frontier for Financing Entrepreneurship? [Online] Available: http://crowdformation.org/UTDCFORM/Research_files/SSRN-id2157429.pdf (May 19, 2014)

Harding, R., Cowlings, M. (2006). Accessing the scale of equity gap. Journal of Small Business and Enterprise Development, 13(1): 115132.

Herrington, Mike, Kew, Jacqui, Kew, Penny (2009), Global Entrepreneurship Monitor, South African report. [Online]. Available: http://www.gbs.nct.ac.za/gbswebb/userfiles/gemsouthafrica2000pdf (October 16, 2013)

Huyghebaert, N. (2006). On the determinant and dynamics of trade credit use: empirical evidence from business start-ups. Journal of Business Finance and Accounting, 33(1) 305-328

Irwin, David, Grayson, Irwin, Scott, Jonathan, (2006), Barriers faced by SMEs in raising finance from banks. [Online] Available: http://www.irwingrayson.com/dloads/isbe06financeBarriers.pdf (June 5, 2014)

Jensen, M.C., Meckling, W.H. (1976). Theory of the firm: managerial behaviour, agency cost and ownership structure. Journal of financial Economics, 3(4): 305-360.

Johannesburg Stock Exchange (2014), The Alt-X exchange. [Online] Available: http//www.jse.org.za.alt/x (April, 30, 2014)

Love, Inessa, (2010) Trade Credit versus Bank Credit during Financial Crises. [Online] Available:http://siteresources.worldbank.org/ Intranettrade/Resources/TradeFinancech01.pdf (April 5, 2014)

Kleemann, F., Vo, G.G., Rieder, K. (2008). Un(der)paid Innovators: The Commercial Utilization of Consumer Work through Crowdsourcing. Science, Technology \& Innovation Studies, 4, 5-26.

Lambert, Thomas, Schwienbacher, Armin. (2010), An Empirical Analysis of Crowdfunding [Online] Available: http://www.crowdsourcing.org/document/an-empirical-analysis-of-crowdfunding-/2458 (May 8, 2014)

Mason, Colin, Harrison, Richard, (2013), Business angel investment activity in the financial crisis: UK evidence and policy implications [Online] Available: http://www.gla.ac.uk/media/media_286594_en.pdf (May 16, 2014)

Mazanai, M., Fatoki, O. (2011). The Effectiveness of Business Development Services Providers (BDS) in Improving Access to Debt Finance by Start-Up SMEs in South Africa. International Journal of Economics and Finance, 3(4): 208-216

Modigliani, F., Miller, M.H. (1958). The cost of capital, corporation finance and the theory of investment. American Economic Review, 48(3):261-295.

Modigliani, F.. \& Miller, M.H. (1963). Corporate income taxes and the cost of capital: A correction. American Economic Review, 53(3): 433-444.

Myers, S.C. (1984). Capital structure puzzle. Journal of Finance, 39(3): 575-592

North, D., Baldock, R., Ekanem, I. (2010). Is there a debt finance gap relating to Scottish SMEs? A demand-side perspective. Venture Capital: An International Journal of Entrepreneurial Finance, 12(3):173-192

Ou, C., Haynes, G.W. (2006). Acquisition of additional equity by small firms; finding from the national survey of small business finance. Journal of Small Business Economics, 27(1): 157-168.

Organisation for Economic Co-operation and Development (2014). Financing SMEs and Entrepreneurs (2014). An OECD Scoreboard. [Online] Available: http://www.oecd.org/industry/smes/ (May 28, 2014)

Park, J., Lim, B., Koo, J. (2008). Developing the Capital Market to widen and diversify SME Financing: The Korean Experience. in Proceedings, Wrap-up Meeting of Consultants/Research Institutes of ASEAN + 3 Research Group (1-61), (Hanoi:, Korean Institute of Finance).

Phaladi, Makgati., Thwala, Wellington (2008), Critical success factor for small and medium sized contractors in North West province, South Africa. [Online] Available: http://www.cib2007.com/papers/cidb2008\%final\%20paper (May 16, 2013)

Robb, Alicia, Robinson, David (2009), The capital structure decision of new firms. [Online]. Available: http://papers.ssrn.com/s013/papers.cfm?abstract-id=1345895 ( October 17, 2013)

Schwienbacher, Armin, Larralde, Benjamin (2010), Crowdfunding of small entrepreneurial ventures [Online] Available: http://www.em-a. eu/fileadmin/content/REALISE_IT_2/REALISE_IT_3/CROWD_OUP_Final_Version.pdf

Scheers, L. (2010). Challenges of small family groceries shops in South Africa. World Journal of Entrepreneurship, Management and Sustainable Development, 6(3), 221 - 231 (June 5, 2014)

Small Enterprise Finance Agency 2014. About us. [Online] Available: http://www.sefa.org.za/ (June 8, 2014)

Stiglitz, J., Weiss, A. (1981). Credit rationing in markets with imperfect information. American Economic Review, 71(3): 393-410.

Timmons, J.A., Spinelli, S. 2007. New venture creation: Entrepreneurship for the 21st century. (7th ed.).New York: McGraw-Hill.

Todor, Ionescu, Alin, Stancu, (2008). Key success factors in new products development process. [online] Available:http://stencinimics .uoradea.ro/anale/volume2007/management-andmarketing (January 10, 2013).

Turton, Natasha, \& Herrington, Mike, (2013), Global Entrepreneurship Monitor South African 2012 Report. [Online]. Available: http://www.gemconsortium.org/docs/2801/gem-south-africa-2012-report (April 18, 2014)

Vanacker, Tom, Mamigart, Sophie, Meuleman, Miguel, Sels Luc (2011), The Impact of Financial Bootstrap Strategies on Value Added in 
New Ventures: A Longitudinal Study. [Online]. Available http://www.gsom.spbu.ru/files/upload/niim/seminar/ (May 5, 2014) Winborg, J. (2008). Use of financial bootstrapping in new businesses: A question of last resort? Venture Capital, 11(1): 71-83.

Wong, P.K., Ho, Y.P., Autio, E. (2005). Entrepreneurship, innovation and economic growth: Evidence from GEM data. Small Business Economics, 24(3): 335-350.

Winton, A., Yerramilli, V. (2008). Entrepreneurial Finance: Banks versus Venture Capital. Journal of Financial Economics, 5(3): 51-79

Zhou, Huan, Chen, Xiaoyun (2008), Resource capabilities and new venture choice. [online]. Available: http://74.125.77.132/search?q= cache:mgr4d29qtqpQ5:www.ceauk.org.uk/20 (May 25, 2013) 